\title{
Anti-inflammatory Effect of Abciximab-Coated Stent in a Porcine Coronary Restenosis Model
}

\begin{abstract}
The aim of this study was to examine the anti-inflammatory effect of abciximab-coated stent in a porcine coronary overstretch restenosis model. Ten abciximab-coated stents, ten sirolimus-eluting stents (SES), and ten paclitaxel-eluting stents (PES) were deployed with oversizing (stent/artery ratio 1.3:1) in porcine coronary arteries, and histopathologic analysis was done at 28 days after stenting. There were no significant differences in the neointima area normalized to injury score and inflammation score among the three stent groups $\left(1.58 \pm 0.43 \mathrm{~mm}^{2}, 1.57 \pm 0.39 \mathrm{~mm}^{2}\right.$ in abciximab-coated stent group vs. $1.69 \pm 0.57 \mathrm{~mm}^{2}, 1.72 \pm 0.49 \mathrm{~mm}^{2}$ in the SES group vs. $1.92 \pm 0.86 \mathrm{~mm}^{2}, 1.79 \pm 0.87 \mathrm{~mm}^{2}$ in the PES group, respectively). In the neointima, most inflammatory cells were lymphohistiocytes. Significant positive correlations were found between the extent of inflammatory reaction and the neointima area $(r=0.567, p<0.001)$ and percent area stenosis $(r=0.587, p<0.001)$. Significant correlations were found between the injury score and neointimal area $(r=$ $0.645, p<0.001)$, between the injury score and the inflammation score $(r=0.837$, $p<0.001)$, and between the inflammation score and neointimal area $(r=0.536, p=$ 0.001 ). There was no significant difference in the inflammatory cell counts normalized to injury score among the three stent groups $(75.5 \pm 23.1 / \mu \mathrm{L}$ in abciximabcoated stent group vs. $78.8 \pm 33.2 / \mu \mathrm{L}$ in the SES group vs. $130.3 \pm 46.9 / \mu \mathrm{L}$ in the PES group). Abciximab-coated stent showed comparable inhibition of inflammatory cell infiltration and neointimal hyperplasia with other drug-eluting stents in a porcine coronary restenosis model.
\end{abstract}

Key Words : Stents; Inflammation; Blood Platelets

\author{
Young Joon Hong, Myung Ho Jeong, \\ Sang Rok Lee, Seo Na Hong, \\ Kye Hun Kim, Hyung Wook Park, \\ Ju Han Kim, Weon Kim, \\ Youngkeun Ahn, Jeong Gwan Cho, \\ Jong Chun Park, Jung Chaee Kang
}

The Heart Center of Chonnam National University Hospital, Chonnam National University Research Institute of Medical Sciences, Gwangju, Korea

Received: 13 September 2006

Accepted : 23 February 2007

\section{Address for correspondence}

Myung Ho Jeong, M.D.

Director of Cardiac Research Laboratory, The Heart Center of Chonnam National University Hospital, 8

Hak-dong, Dong-gu, Gwangju 501-757, Korea Tel : +82.62-220-6243, Fax : +82.62-228-7174 E-mail : myungho@chollian.net

*This study was supported by grants from Clinical Trial Center of Chonnam National University (CUHRICM-U200639), Korean Ministry of Health and Welfare, and Cardiovascular Research Foundation Asia.

\section{INTRODUCTION}

Although the implantation of coronary stents can prevent vessels from post-interventional elastic recoil and appears to limit adverse remodeling, the problem of restenosis and the need for consecutive reinterventions remains the major limitation of stent implantation (1-3). The mechanism of instent restenosis (ISR) after stent implantation is principally neointimal hyperplasia (4-8). It has been reported that there is a strong correlation between the degree of vascular inflammation and neointimal formation $(9,10)$. The pathological process of ISR is characterized by an inflammatory healing process after stretch and damage of the vessel wall (10-12).

Based on observations that ISR is a consequence of inflammation and smooth muscle cell proliferation, several immunosuppressive and anti-proliferative therapies have been investigated to inhibit these processes. Sirolimus is a potent immunosuppressive agent with anti-inflammatory and anti-proliferative effects. Previous studies of sirolimus-eluting stent (SES) have shown a range of biological effects on inflamma- tion and neointimal growth (13-15). Paclitaxel suppresses neointimal formation accompanied by persistent fibrin deposition, macrophage infiltration, and an overall decrease in smooth muscle cells after implantation (16-18).

Abciximab is a potent inhibitor that block the final pathway of platelet aggregation and decreases short- and longterm event rates after percutaneous coronary intervention (19-21). Besides blocking effect for platelet aggregation, abciximab reacts to $\alpha \mathrm{V} \beta 3$ receptor of vascular smooth muscle cell and to Mac-1 of macrophage and inhibits proliferation of vascular smooth muscle cells and inflammatory reaction (22-26). Our previous study showed that abciximabcoated stent reduced stent restenosis by inhibition of cell proliferation and extracellular matrix synthesis compared with bare-metal stent in a porcine coronary restenosis model (27-29).

We examined the anti-inflammatory effect of abciximabcoated stent and compared with that of SES and with that of paclitaxel-eluting stent (PES) in a porcine coronary overstretch restenosis model. 


\section{MATERIALS AND METHODS}

\section{Animal study protocol}

The animal study was approved by the Ethical Committee of the Chonnam National University Hospital in Gwangju, Korea. Study animals were female swine weighing $22-35 \mathrm{~kg}$. To decrease acute thrombosis after stenting, premedication with aspirin $100 \mathrm{mg}$ and clopidogrel $75 \mathrm{mg}$ per day was given for 5 days before procedure. On the day of the stent implantation, pigs were anesthetized with ketamine $(20 \mathrm{mg} /$ $\mathrm{kg}$ intramuscularly) and xylazine ( $2 \mathrm{mg} / \mathrm{kg}$ intramuscularly). They received $3 \mathrm{~L} / \mathrm{min}$ of supplemental oxygen continuously through oxygen mask. After subcutaneous lidocaine $2 \%$ at the cut-down site was administered, left carotid artery was surgically exposed, and a 7-8F sheath was inserted. Continuous hemodynamic and surface electrocardiographic monitoring was maintained throughout the procedure. After Heparin 10,000 uints was administered intravenously as a bolus prior to the procedure, the target coronary artery was engaged using standard $7-8 \mathrm{~F}$ guide catheters, and control angiograms of the both coronary arteries were performed using nonionic contrast agent in two orthogonal views.

\section{Method of coating abciximab into stents}

A plasma polymerization reaction was performed to attach amine radical to MAC stent (AMG, Munich, Germany) surface. A stent was fixed in tubular reactor, which was made by pyrex glass tube, and then the pressure was dropped to less than 5 mtorr by vacuum pump. For attachment of amine radical to stent surface, diaminocyclohexane monomer was drifted to tubular reactor a constant dose (0.96 SCCM), and plasma was generated using at a radiofrequency power generator. The power for polymerization of plasma was $100 \mathrm{~W}$ for $5 \mathrm{~min}$ and then $60 \mathrm{~W}$ for $15 \mathrm{~min}$. The used abciximab is a human-murine chimeric antibody Fab fragment (c7E3 Fab) and blocks glycoprotein IIb/IIIa receptor directly. A 7 cm-long, $1 \mathrm{~cm}$-wide glass tube was boiled in $100^{\circ} \mathrm{C}$ water for $5 \mathrm{~min}$ and then taken out and allowed to dry in an incubator. Then $2 \mathrm{~mL}$ of abciximab solution was delivered to this glass tube, and the stent was immersed in this solution. The carboxy radical of abciximab was introduced to amine radical attached to stent to achieve covalent bond and improved attachment power between stent and abciximab. This reaction was performed for $1 \mathrm{hr}$ and then stent was taken out and allowed to dry for more than $24 \mathrm{hr}$. For release kinetics of abciximab from the stent, the stent was placed in glass vial and immersed in $100 \mathrm{~mL}$ of phosphate-buffered saline. We confirmed coating of abciximab onto the surface of the stent by scanning electron microscopy. The amount of coating of abciximab onto the surface of the stent was $90 \mu \mathrm{g} / \mathrm{stent}$, and the median thickness of coating was $1 \mu \mathrm{m}$. The amount of abciximab release to buffer solution was measured using ab- sorbance test for ultraviolet at $278 \mathrm{~nm}$. The amount of abciximab release increased with the time and remained on the stent surface 1 month after coating of abciximab to the stent.

\section{Stent- induced stenosis}

Besides abciximab-coated stent, we used two commercially available U.S. Food and Drug Administration-approved drug-eluting stent platforms Sirolimus (Cypher stent, Cordis, Johnson and Johnson, Miami Lakes, FL, U.S.A.) and Paclitaxel (Taxus stent, Boston Scientific, Boston, MA, U.S.A.). The used size and length of stents were $3.0 \times 17 \mathrm{~mm}$ abciximab-coated stents, $3.0 \times 18 \mathrm{~mm} \mathrm{SES}$, and $3.0 \times 16 \mathrm{~mm}$ PES. The stent was deployed by inflating the balloon to nominal pressure at injury site, and the resulting stent-toartery ratio was 1.3:1. Repeated angiograms were obtained immediately after stent implantation. Then, all equipments were removed, and the carotid artery was ligated. All animals received $100 \mathrm{mg}$ of aspirin and $75 \mathrm{mg}$ of clopidogrel orally daily until death. Twenty-eight days after stenting, the animals underwent repeated angiography in the same orthogonal views before death, and $20 \mathrm{~mL}$ of potassium chloride intracoronary injection was done. The hearts were removed, and the coronary arteries were pressure-perfusion fixed at $70 \mathrm{mmHg}$ in $10 \%$ neutral-buffered formalin overnight. Arteries were step-sectioned, processed routinely for light microscopy, and stained with hematoxylin-eosin stain for histological analysis.

\section{Histopathological analysis}

Histopathologic evaluation of each artery was performed by an experienced cardiovascular pathologist. The specimens were embedded in methylmethacrylate, and sections were cut with the low-speed diamond wafer mounted to the Buehler Isomet saw (Buehler Ltd., Lake Bluff, IL, U.S.A.), leaving the stent wires intact in the cross sections to minimize potential artifacts from removal of stent wires. Sections of 50- to $100-\mu \mathrm{m}$ thickness were obtained at about $1 \mathrm{~mm}$ apart and stained with hematoxylin-eosin for histological analysis. Measurements of the histopathologic sections were performed using a calibrated microscope, digital video imaging system, and microcomputer program (Visus 2000 Visual Image Analysis System, IMT Tech., CA, U.S.A.). Borders were manually traced for lumen area, area circumscribed by the internal elastic lamina, and the innermost border of the external elastic lamina (external elastic lamina area). Morphometric analysis of the neointimal area for a given vessel was calculated as the measured internal elastic lamina area minus lumen area. The measurements were made on five cross-sections from the proximal and distal ends and the three midpoints of each stented segment. Histopathologic stenosis was calculated as $100 \times(1-$ lesion lumen area/lesion internal elastic lamina area]). 


\section{Evaluation of arterial injury}

Arterial injury at each strut site was determined by the anatomic structures penetrated by each strut. A numeric value was assigned, as previously described by Schwartz et al.: $0=$ no injury; $1=$ break in the internal elastic membrane; $2=$ perforation of the media; 3 =perforation of the external elastic membrane to the adventitia (30). The average injury score for each segment was calculated by dividing the sum of injury scores by the total number of struts at the examined section.

\section{Evaluation of inflammation scores and neointimal reaction}

With regard to the inflammation score for each individual strut, the grading was as follows: $0=$ no inflammatory cells surrounding the strut; $1=$ light, noncircumferential lymphohistiocytic infiltrate surrounding strut; $2=$ localized, moderate to dense cellular aggregate surrounding the strut noncircumferentially; and 3 =circumferential dense lymphohistiocytic cell infiltration of the strut. The inflammation score for each cross section was calculated by dividing the sum of the individual inflammation scores by the total number of struts at the examined section. Inflammatory cell counts were normalized to injury score in neointima and compared among three stent groups.

\section{Statistical analysis}

Statistical analysis was performed with the aid of the commercially available software (SPSS Version 11, Chicago, IL, U.S.A.). The data were presented as mean value $\pm S D$. Unpaired Student's t test was used for the comparison of inflammatory cell counts normalized to injury score of the two stent groups. Analysis of variance (ANOVA) was used for comparisons of the three stent groups. To examine the correlations between the measured histologic variables, regression analysis was applied for each set of measured variables. A value of $p<0.05$ was considered statistically significant.

\section{RESULTS}

\section{Procedural characteristics}

Two stents were placed for two coronary arteries per one pig. A total of thirty stents including ten abciximab-coated setnts, ten SESs, and ten PESs, were placed in the proximal
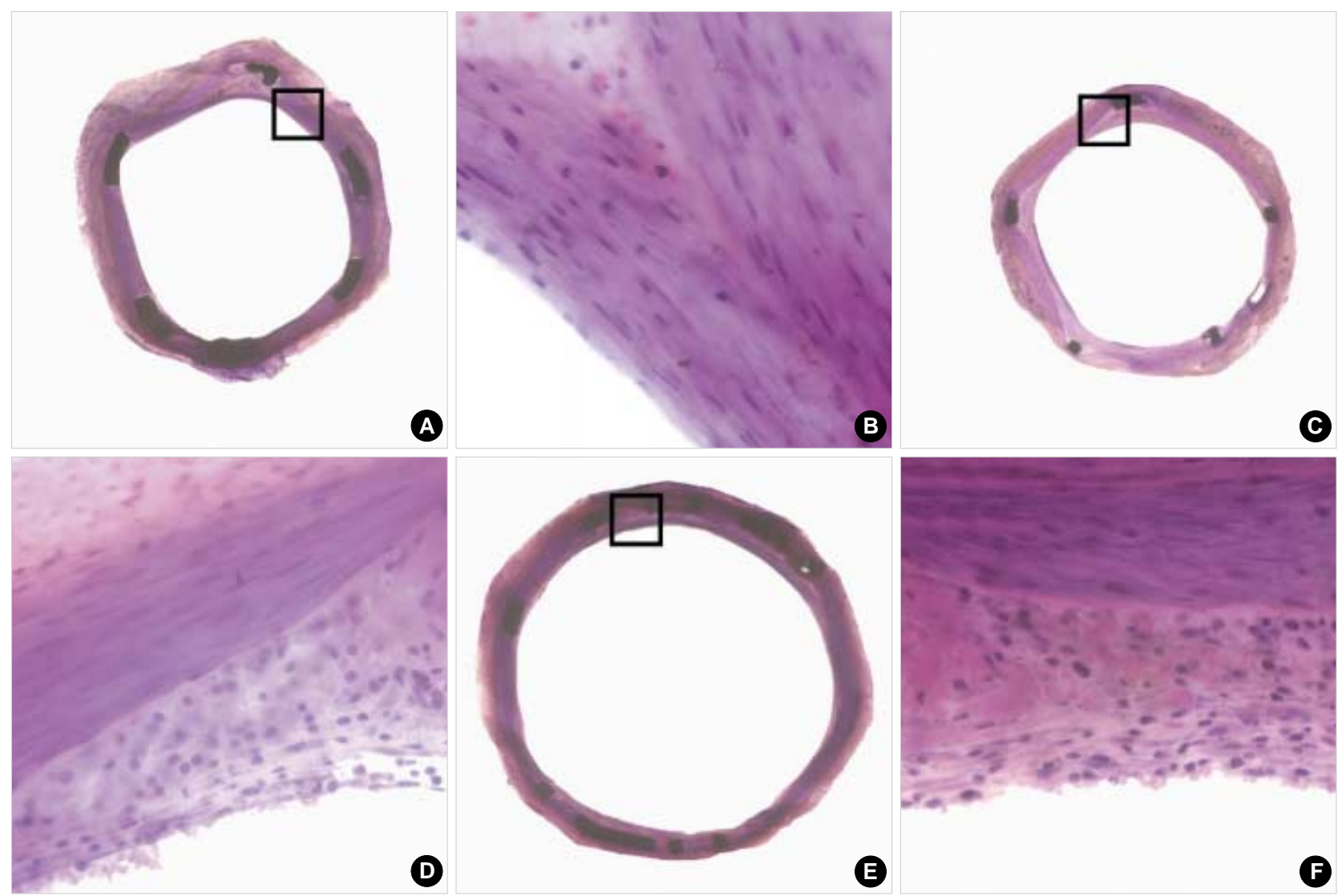

Fig. 1. The hematoxylin-eosin stain of the low- and high-power fields (magnitude, $\times 20, \times 400$ ) of neointimal hyperplasia and inflammatory cell infiltration in abciximab-coated stent $(A, B)$, sirolimus-eluting stent $(C, D)$, and paclitaxel-eluting stent $(E, F)$. 
left anterior descending, proximal circumflex, and proximal right coronary artery for fifteen pigs (Table 1). Mortality for this study was zero. Quantitative coronary angiography before and after stent implantation established the stent-to-artery diameter ratio as $1.336 \pm 0.061$ for all 30 stented arteries. There was no significant difference in stent-to-artery ratio among three stent groups.

\section{Neointimal response to injury}

The lumen area, neointima area, and percent area stenosis at 28 days after stent implantation were not different significantly among three stent groups (Fig. 1, Table 2). Although there was a trend that the average injury score for each segment was higher in the PES group, this was not statistically significant (Table 2). There were no significant differences in the neointima area normalized to injury score and inflammation score among the three stent groups (neointima area normalized to injury score; $1.58 \pm 0.43 \mathrm{~mm}^{2}$ in the abciximab-coated stent group vs. $1.69 \pm 0.57 \mathrm{~mm}^{2}$ in the SES group vs. $1.92 \pm 0.86 \mathrm{~mm}^{2}$ in the PES group, and neointima area normalized to inflammation score; $1.57 \pm 0.39 \mathrm{~mm}^{2}$ in the abciximab-coated stent group vs. $1.72 \pm 0.49 \mathrm{~mm}^{2}$ in the SES group vs. $1.79 \pm 0.87 \mathrm{~mm}^{2}$ in the PES group, respectively) (Fig. 2).

\section{Neointimal response to inflammation}

Although there was a trend that the inflammation score for each cross-section was higher in the PES group, this was

Table 1. Stented porcine coronary arteries

\begin{tabular}{lccc}
\hline & $\begin{array}{c}\text { Abciximab- } \\
\text { coated stent } \\
(\mathrm{n}=10)\end{array}$ & $\begin{array}{c}\text { Sirolimus- } \\
\text { eluting stent } \\
(\mathrm{n}=10)\end{array}$ & $\begin{array}{c}\text { Paclitaxel- } \\
(\mathrm{n}=10)\end{array}$ \\
\hline Left anterior descending artery & 4 & 3 & 3 \\
Left circumflex artery & 2 & 2 & 4 \\
Right coronary artery & 4 & 5 & 3 \\
\hline
\end{tabular}

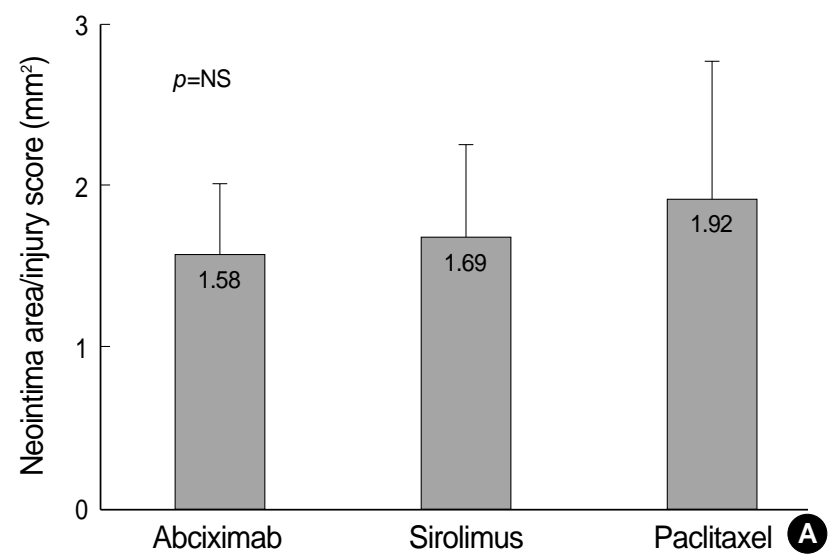

not statistically significant (Table 2). All the sections examined revealed various amounts of inflammatory infiltrate surrounding at least one or more of the struts. In neointima, most inflammatory cells were lymphohistiocytes. The inflammatory reaction consisted of groups of pale histiocytic cells adjacent to the struts with occasional multinucleated giant cells. A rim of small, dark lymphocytes was also noted at the periphery, along with fibroblasts and capillaries. In contrast, eosinophils and plasma cells were not prominent (Fig. 1). A significant positive correlations were found between lymphohistiocyte count and the neointimal area $(\mathrm{r}=0.551$, $p=0.001$ ), and between lymphohistiocyte count and percent area stenosis $(\mathrm{r}=0.620, p=0.001)$ (Fig. 3). This correlation between lymphohistiocyte count and neointimal formation was similarly observed among three stent groups. Significant correlations were found between the injury score and neointimal area $(\mathrm{r}=0.645, p<0.001)$, between the injury score and the inflammation score $(\mathrm{r}=0.837, p<0.001)$, and between the inflammation score and neointimal area $(\mathrm{r}=$ 0.536, $p=0.001$ ) (Fig. 4).

\section{Inflammatory reaction according to the stent type, injury score, and inflammation score}

Because there was a strong trend that injury score and in-

Table 2. Coronary artery morphometric measurements in thirty stented vessels

\begin{tabular}{lcccc}
\hline & $\begin{array}{c}\text { Abciximab- } \\
\text { coated stent } \\
(\mathrm{n}=50)\end{array}$ & $\begin{array}{c}\text { Sirolimus- } \\
\text { eluting stent } \\
(\mathrm{n}=50)\end{array}$ & $\begin{array}{c}\text { Paclitaxel- } \\
\text { eluting stent } \\
(\mathrm{n}=50)\end{array}$ & $\begin{array}{c}p \\
\text { value }\end{array}$ \\
\hline IEL area $\left(\mathrm{mm}^{2}\right)$ & $19.8 \pm 4.4$ & $19.7 \pm 5.8$ & $21.7 \pm 8.5$ & $\mathrm{NS}$ \\
Lumen area $\left(\mathrm{mm}^{2}\right)$ & $17.9 \pm 4.1$ & $17.5 \pm 5.1$ & $18.9 \pm 7.5$ & $\mathrm{NS}$ \\
Neointima area $\left(\mathrm{mm}^{2}\right)$ & $1.9 \pm 0.8$ & $2.2 \pm 1.1$ & $2.8 \pm 1.6$ & $\mathrm{NS}$ \\
\% area stenosis & $9.6 \pm 5.0$ & $11.2 \pm 6.0$ & $12.9 \pm 8.6$ & $\mathrm{NS}$ \\
Injury score & $1.20 \pm 0.40$ & $1.30 \pm 0.54$ & $1.46 \pm 0.85$ & $\mathrm{NS}$ \\
Inflammation score & $1.21 \pm 0.35$ & $1.28 \pm 0.47$ & $1.56 \pm 0.85$ & $\mathrm{NS}$ \\
\hline
\end{tabular}

IEL, internal elastic lamina; NS, not significant.

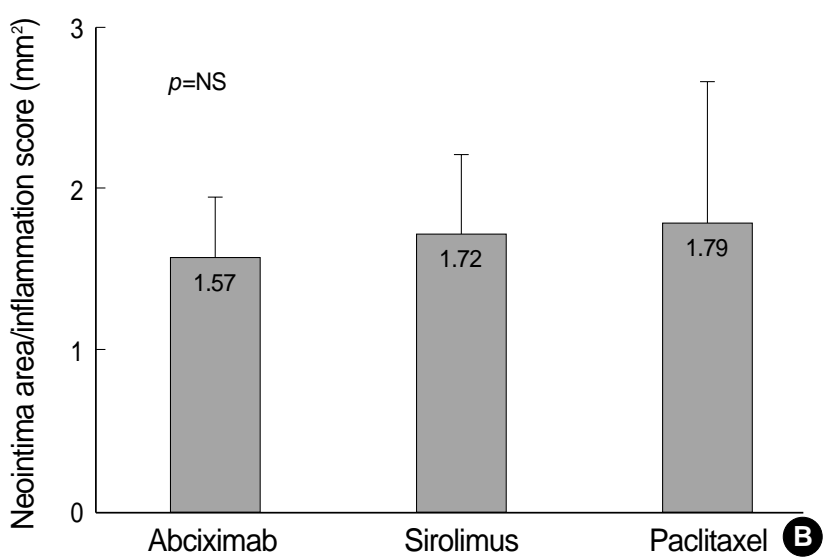

Fig. 2. The neointima area normalized to injury score $(A)$ and inflammation score $(B)$ in the three types of stents. 

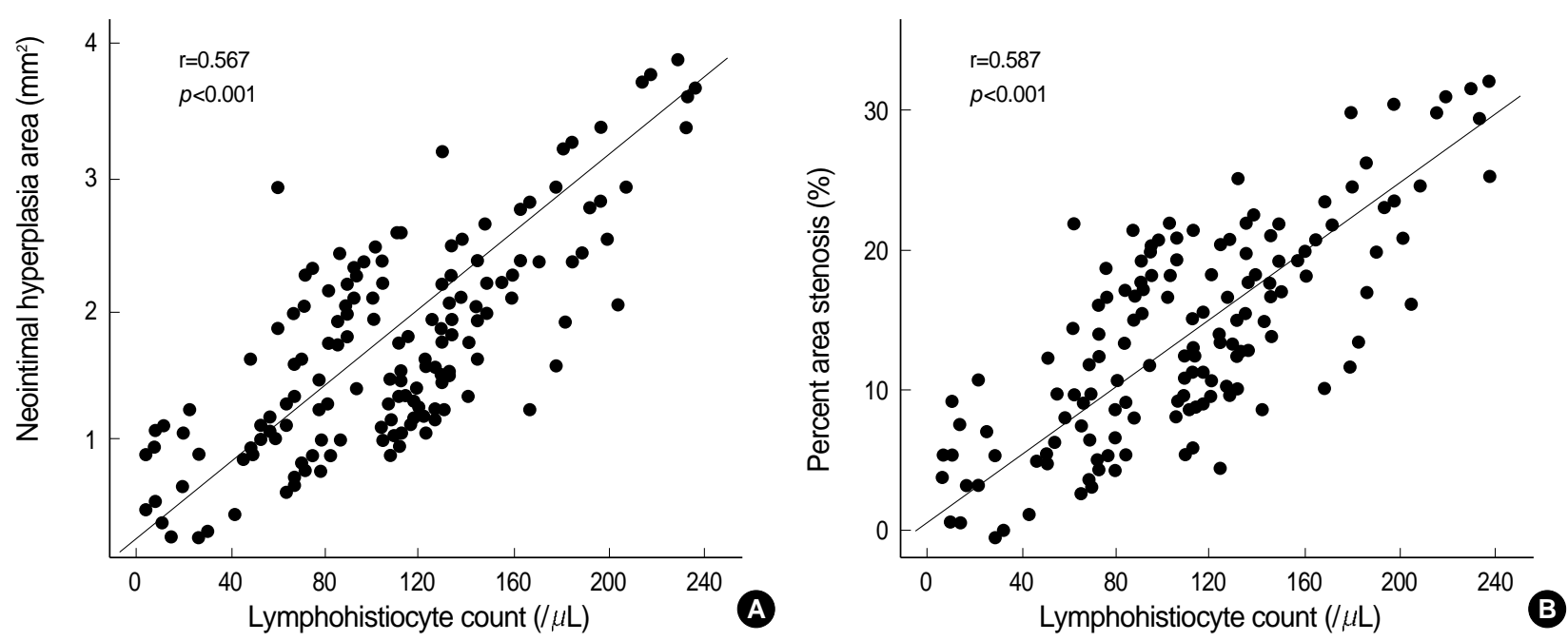

Fig. 3. Correlations between the lymphohistiocyte count and (A) neointimal area and (B) percent area stenosis.
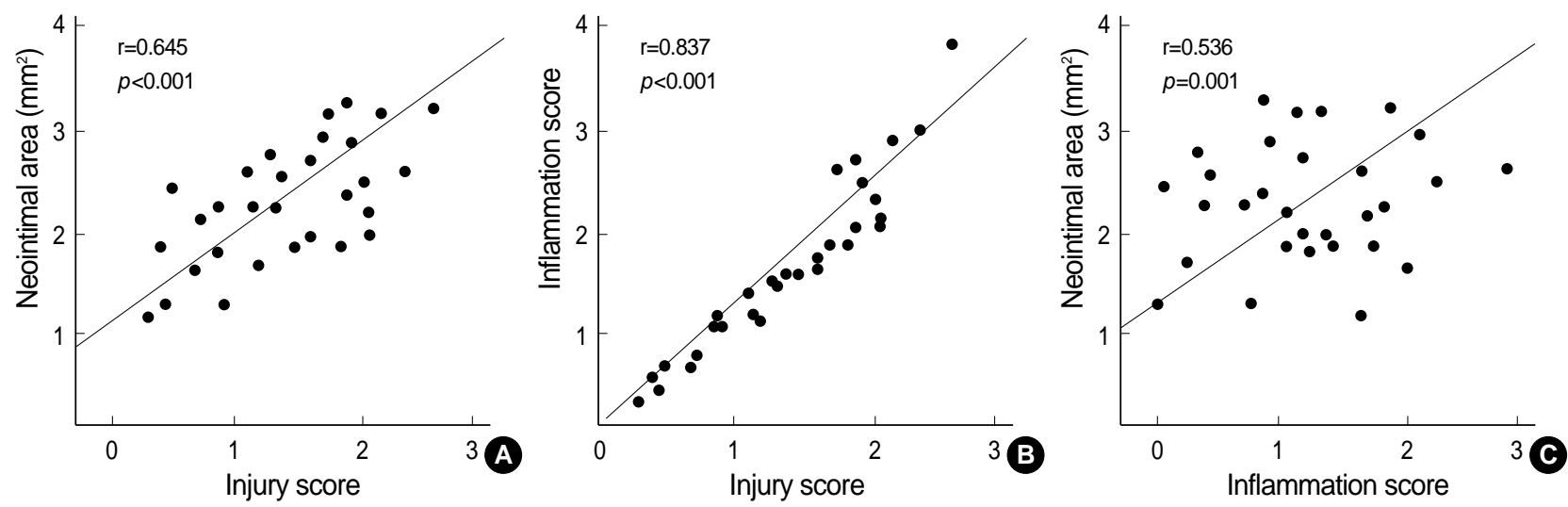

Fig. 4. Correlations between the injury score and neointimal area $(A)$, between the injury score and the inflammation score $(B)$, and between the inflammation score and neointimal area $(\mathrm{C})$.

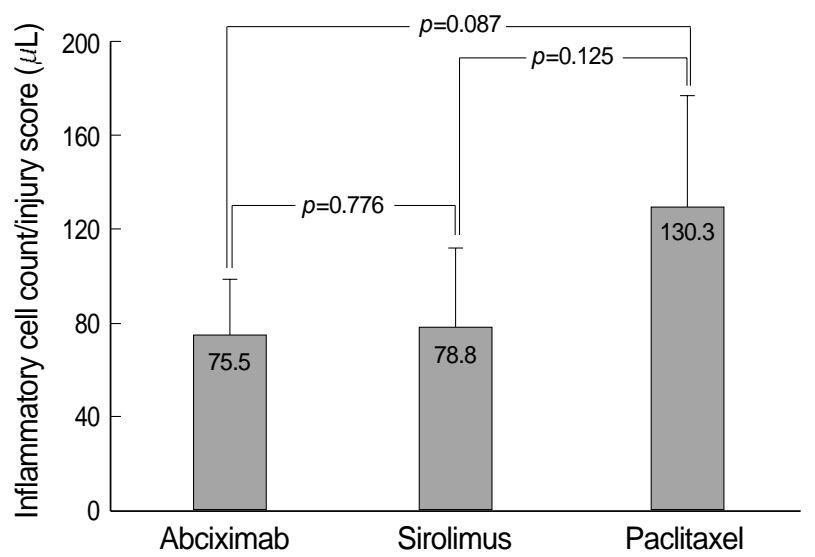

Fig. 5. The neointimal inflammatory cell count normalized to injury score in the three types of stents.

flammation score were higher in the PES group and there was a correlation between the injury score and the inflammation score, we evaluated inflammatory cell infiltration normalized to the injury score. Although there was a strong trend that inflammatory cell counts normalized to the injury score was lower in the abciximab-coated stent group compared to the PES group, this was not statistically significant $(75.5 \pm 23.1 / \mu \mathrm{L}$ the in abciximab-coated stent group vs. $78.8 \pm 33.2 / \mu \mathrm{L}$ in the SES group vs. $130.3 \pm 46.9 / \mu \mathrm{L}$ in the PES group) (Fig. 5).

\section{DISCUSSION}

This study demonstrated that abciximab-coated stent showed comparable anti-inflammatory effect and comparable inhibition of neointimal hyperplasia with other drug-eluting stents in a porcine coronary restenosis model. ISR due to neointimal hyperplasia remains the major limitation of coronary stents (4-8). There is increasing evidence that inflammation plays an important role in the initiation and development of neointimal hyperplasia and subsequent restenosis $(9,10)$.

Because of the role of inflammatory cells in restenosis, these cells seemed to be an optimal target in the fight against res- 
tenosis. The pathological process of ISR is characterized by an inflammatory healing response after stretch and damage of the vessel wall. Initially, platelets are activated and attach around the stent struts followed by adhesion of inflammatory cells. Cytokines and growth factors are released, leading to smooth muscle cell migration and proliferation (10-12). Therefore, modulation of the inflammatory response is expected to decrease ISR. Several immunosuppressive and antiproliferative therapies have been investigated to inhibit these processes (31-35). Recent successes in early clinical trials with drug-eluting stents using the anti-proliferative agents Sirolimus (rapamycin) and Paclitaxel (Taxol) have been quite promising (36-38).

Our previous study showed that abciximab-coated stent reduced neointimal hyperplasia by inhibition of neointimal cell proliferation and extracellular matrix synthesis compared to bare-metal stent in a porcine coronary restenosis model (27-29). In our previous study (29), the area of neointima of abciximab-coated stent was reduced to $45.7 \%$ and $45.5 \%$ of the control bare-metal stent at 28 days and 56 days after stenting, respectively, the content ratio of proteoglycan within the neointima of abciximab-coated stent was reduced to $23 \%$ of the control bare-metal stent at 14 days after stenting, the content ratio of collagen within the neointima of abciximab-coated stent was reduced to $19.7 \%$ and $25 \%$ of the control bare-metal stent at 28 days and 56 days after stenting, respectively, proliferating cell nuclear antigen index of neointima of abciximab-coated stent was reduced to $22.2 \%$ of the control bare-metal stent at 14 days after stenting, and the apoptosis of abciximab-coated stent by TUNEL analysis during a 56-day follow-up after stent implantation was not different compared to control bare-metal stent. We previously reported that abciximab-coated stent was feasible and produced a significant inhibition of neointimal hyperplasia, showing a potential therapeutic benefit in the prevention of stent restenosis in human trials $(39,40)$. In this study, we suggested that the possible mechanisms responsible for inhibition of neointimal hyperplasia by abciximab might be antiplatelet, anti-inflammatory, and anti-proliferative actions.

Platelet activation and aggregation induces arterial thrombosis and plays a pivotal role in the pathophysiology of acute coronary syndromes $(41,42)$. Platelets have been incriminated in contributing to neointimal hyperplasia via the release of platelet-derived growth factor that induces smooth muscle cell proliferation and migration. By virtue of the ability of platelets to facilitate the generation of thrombin, they may also act as a smooth muscle cell mitogen. Additionally, platelets express multiple counterreceptors for leukocytes, thereby providing a nidus for vessel wall inflammation.

A glycoprotein II/IIIa receptor blocker, abciximab, is a potent inhibitor that block the final pathway of platelet aggregation and decreases short- and long-term event rates after percutaneous coronary intervention (19-21). Besides the blocking effect for platelet aggregation, the blockade of the glycoprotein IIb/IIIa receptor by abciximab may inhibit the interaction between platelets and leukocytes, and hence limit the inflammatory response to coronary intervention. Abciximab cross-reacts and inhibits $\alpha \mathrm{V} \beta 3$. The $\alpha \mathrm{V} \beta 3$ receptor has also been implicated in neointimal hyperplasia since smooth muscle cells express $\alpha \mathrm{V} \beta 3$ receptors that are upregulated further after vascular injury (22). Moreover, in a number of different animal models, the inhibition of $\alpha \mathrm{V} \beta 3$ receptors has resulted in decreased neointimal thickening. Abciximab has cross-reactivity with other integrin receptors, including Mac-1, which is a major fibrinogen receptor on the polymorphonuclear neutrophil surface, and inhibits inflammatory reaction (23-26).

In the present study, significant positive correlations were found between the extent of inflammatory reaction and the neointimal area and between the extent of inflammatory reaction and percent area stenosis, respectively. Although the degrees of arterial injury correlated with inflammation score and neointimal area and there was a trend that injury score and inflammation score were higher in the PES group, inflammatory cell infiltration normalized to injury score was not different significantly among three stent groups. Thus, abciximab-coated stent might prevent ISR via a comparable antiinflammatory effect with other drug-eluting stents.

There are several limitations to be mentioned. Firstly, it remains to be established whether our findings in normal nonatherosclerotic porcine coronary arteries stimulated with oversized stents for neointimal proliferation could be extrapolated to human clinical scenarios with preexisting atherosclerosis and stent sizes matched to the reference vessel. Secondly, our study did not examine the early inflammatory response, as there is little neointimal formation at that time. Thirdly, although there was a trend toward larger neointima area in the PES group, injury score also had a trend for increase in this group, and injury score correlated with inflammation score and neointimal formation. This may suggest the extent of injury against intima by overstreching of oversized stent is related with inflammatory reaction and reactive hyperplasia. Fourthly, although the functional impact of abciximab might involve the reduced formation of leukocyte-platelet coaggregates, we did not demonstrate whether abciximabcoated stent inhibits formation of leukocyte-platelet aggregates. Thus, further studies are needed to demonstrate whether abciximab-coated stent may inhibit the interaction between platelets and leukocytes. Fifthly, we did not have a true control group. We compared different stent designs, lengths, and polymer drug combinations. Given these model that induces fairly minimal stenosis, it might not be clear that we had sufficient numbers to show that there would be a difference between a true control group and drug-eluting stents. Sixthly, we examined the histology of inflammation on H\&E stain. It would be more appropriate and accurate to utilize immunohistochemistry, which is the standard for these types of studies and with appropriate techniques em- 
ployed on resin-embedded sections.

In conclusion, abciximab-coated stent showed a comparable inhibitory effect for inflammatory cell infiltration and neointimal hyperplasia with other drug-eluting stents in a porcine coronary restenosis model.

\section{REFERENCES}

1. Faxon DP, Spiro TE, Minor S, Cote G, Douglas J, Gottlieb R, Califf R, Dorosti K, Topol E, Gordon JB. Low molecular weight heparin in prevention of restenosis after angioplasty. Results of Enoxaparin Restenosis (ERA) Trial. Circulation 1994; 90: 908-14.

2. Hamm CW, Reimers J, Ischinger T, Rupprecht HJ, Berger J, Bleifeld W. A randomized study of coronary angioplasty compared with bypass surgery in patients with symptomatic multivessel coronary disease. German Angioplasty Bypass Surgery Investigation (GABI). N Engl J Med 1994; 331: 1037-43.

3. Kent KM, Bentivoglio LG, Block PC, Bourassa MG, Cowley MJ, Dorros G, Detre KM, Gosselin AJ, Gruentzig AR, Kelsey SF. Longterm efficacy of percutaneous transluminal coronary angioplasty (PTCA): report from the National Heart, Lung, and Blood Institute PTCA Registry. Am J Cardiol 1984; 53: 27-31.

4. Forrester JS, Fishbein M, Helfant R, Fagin J. A paradigm for restenosis based on cell biology: clues for the development of new preventive therapies. J Am Coll Cardiol 1991; 17: 758-69.

5. Austin GE, Ratliff NB, Hollman J, Tabei S, Phillips DF. Intimal proliferation of smooth muscle cells as an explanation for recurrent coronary artery stenosis after percutaneous transluminal coronary angioplasty. J Am Coll Cardiol 1985; 6: 369-75.

6. Bae Y, Jeong MH, Ahn YK, Park JH, Cho JG, Park JC, Kang JC, Park OK. Comparison of porcine coronary stent restenosis between MAC (Maximal Arterial Re-Creation) stent and Palmaz-Schatz stent. Korean Circ J 1998; 28: 89-96.

7. Giraldo AA, Esposo OM, Meis JM. Intimal hyperplasia as a cause of restenosis after percutaneous transluminal coronary angioplasty. Arch Pathol Lab Med 1985; 109: 173-5.

8. Ahn YK, Jeong MH, Kim JW, Kim SH, Cho JH, Cho JG, Park CS, Juhng SW, Park JC, Kang JC. Preventive effects of the heparincoated stent on restenosis in the porcine model. Catheter Cardiovasc Interv 1999; 48: 324-30.

9. Hong YJ, Jeong MH, Lim SY, Lee SR, Kim KH, Sohn IS, Park HW, Kim JH, Kim W, Ahn Y, Cho JG, Park JC, Kang JC. Elevated preprocedural high-sensitivity $C$-reactive protein levels are associated with neointimal hyperplasia and restenosis development after successful coronary artery stenting. Circ J 2005; 69: 1477-83.

10. Kornowski R, Hong MK, Tio FO, Bramwell O, Wu H, Leon MB. In-stent restenosis: contributions of inflammatory responses and arterial injury to neointimal hyperplasia. J Am Coll Cardiol 1998; 31: 224-30.

11. Grewe PH, Deneke T, Machraoui A, Barmeyer J, Muller KM. Acute and chronic tissue response to coronary stent implantation: pathologic findings in human specimen. J Am Coll Cardiol 2000; 35: 157 63.
12. Farb A, Sangiorgi G, Carter AJ, Walley VM, Edwards WD, Schwartz RS, Virmani R. Pathology of acute and chronic coronary stenting in humans. Circulation 1999; 99: 44-52.

13. Klugherz BD, Llanos G, Lieuallen W, Kopia GA, Papandreou G, Narayan P, Sasseen B, Adelman SJ, Falotico R, Wilensky RL. Twenty-eight-day efficacy and phamacokinetics of the sirolimus-eluting stent. Coron Artery Dis 2002; 13: 183-8.

14. Suzuki T, Kopia G, Hayashi S, Bailey LR, Llanos G, Wilensky R, Klugherz BD, Papandreou G, Narayan P, Leon MB, Yeung AC, Tio F, Tsao PS, Falotico R, Carter AJ. Stent-based delivery of sirolimus reduces neointimal formation in a porcine coronary model. Circulation 2001; 104: 1188-93.

15. Carter AJ, Aggarwal M, Kopia GA, Tio F, Tsao PS, Kolata R, Yeung AC, Llanos G, Dooley J, Falotico R. Long-term effects of polymerbased, slow-release, sirolimus-eluting stents in a porcine coronary model. Cardiovasc Res 2004; 63: 617-24.

16. Heldman AW, Cheng L, Jenkins GM, Heller PF, Kim DW, Ware M Jr, Nater C, Hruban RH, Rezai B, Abella BS, Bunge KE, Kinsella JL, Sollott SJ, Lakatta EG, Brinker JA, Hunter WL, Froehlich JP. Paclitaxel stent coating inhibits neointimal hyperplasia at 4 weeks in a porcine model of coronary restenosis. Circulation 2001; 103: 2289-95.

17. Drachman DE, Edelman ER, Seifert P, Groothuis AR, Bornstein DA, Kamath KR, Palasis M, Yang D, Nott SH, Rogers C. Neointimal thickening after stent delivery of paclitaxel: change in composition and arrest of growth over six months. J Am Coll Cardiol 2000; 36: 2325-32.

18. Farb A, Heller PF, Shroff S, Cheng L, Kolodgie FD, Carter AJ, Scott DS, Froehlich J, Virmani R. Pathological analysis of local delivery of paclitaxel via a polymer-coated stent. Circulation 2001; 104: 473-9.

19. EPIC (Evaluation of 7E3 in Preventing Ischemic Complications) Investigators. Use of a monoclonal antibody directed against the platelet glycoprotein IIb/IIIa receptor in high-risk coronary angioplasty. N Engl J Med 1994; 330: 956-61.

20. EPILOG (Evaluation in PTCA to improve Long-Term outcome GP IIb/IIIIa Blockade Study Group) Investigators. Platelet glycoprotein IIb/IIIa receptor blockade and low-dose heparin during percutaneous coronary revascularization. $N$ Engl J Med 1997; 336: 1689-96.

21. CAPTURE (C7E3 Fab AntiPlatelet Therapy in Unstable Refractory angina) Investigators. Randomized placebo-controlled trial of abciximab before and during coronary intervention in refractory unstable angina. Lancet 1997; 349: 1429-35.

22. Srivatsa SS, Fitzpatrick LA, Tsao PW, Reilly TM, Holmes DR Jr, Schwartz RS, Mousa SA. Selective alpha v beta 3 integrin blockade potently limits neointimal hyperplasia and lumen stenosis following deep coronary arterial stent injury: evidence for the functional importance of integrin alpha $v$ beta 3 and osteopontin expression during neointima formation. Cardiovasc Res 1997; 36: 408-28.

23. Shappell SB, Toman C, Anderson DC, Taylor AA, Entman ML, Smith CW. Mac-1 (CD11b/CD8) mediates adherence-dependent hydrogen peroxide production by human and canine neutrophils. $J$ Immunol 1990; 144: 2702-11.

24. Simon DI, XU H, Ortlepp S, Rogers C, Rao NK. 7E3 monoclonal antibody directed against the platelet glycoprotein IIb/IIIa cross- 
reacts with the leukocyte integrin Mac-1 and blocks adhesion to fibrinogen and ICAM-1. Thromb Vasc Biol 1997; 17: 528-35.

25. Mickelson JK, Ali MN, Kleiman NS, Lakkis NM, Chow TW, Hughes BJ, Smith CW. Chimeric 7E3 Fab (ReoPro) decreases detectable CD IIb on neutrophils from patients undergoing coronary angioplasty. J Am Coll Cardiol 1999; 33: 97-106.

26. Lefkovits J, Topol EJ. Platelet glycoprotein IIb/IIIa receptor antagonists in coronary artery disease. Eur Heart J 1996; 17: 9-18.

27. Kang KT, Jeong MH, Kim NH, Rhew JY, Lee SH, Park JC, Lee SU, Kim KH, Choi MJ, Ahn YK, Cho JG, Choi WJ, Cho DL, Park JT, Kang JC. The inhibitory effect of platelet glycoprotein IIb/IIIa receptor blocker-coated stent on porcine coronary stent restenosis. Korean J Med 2001; 60: 314-23.

28. Park OY, Jeong MH, Kim JH, Kim W, Lee SH, Hong YJ, Kim JH, Park WS, Kim IS, Choi MJ, Ahn YK, Park JT, Cho JG, Park JC, Cho DL, Kang JC. The inhibitory effects of platelet glycoprotein IIb/IIIa receptor blocker-coated stent on neointima formation and inflammatory response in porcine coronary stent restenosis. Korean Circ J 2003; 33: 439-45.

29. Hong YJ, Jeong MH, Kim W, Lim SY, Hong SN, Lee SH, Kim KH, Yun KH, Kang DG, Lee YS, Park HW, Kim JH, Ahn Y, Cho JG, Park JT, Park CS, Park JC, Kang JC. The effects of abciximab (ReoPro(r))-coated stents on extracellular matrix synthesis and apoptosis. Korean Circ J 2005; 35: 290-301.

30. Schwartz RS, Huber KC, Murphy JG, Edwards WD, Camrud AR, Vlietstra RE, Holmes DR. Restenosis and the proportional neointimal response to coronary artery injury: results in a porcine model. J Am Coll Cardiol 1992; 19: 267-74.

31. Salame MY, Verheye S, Crocker IR, Chronos NA, Robinson KA, King SB 3rd. Intracoronary radiation therapy. Eur Heart J 2001; 22: 629-47.

32. Faxon DP. Systemic drug therapy for restenosis: "deja vu all over again”. Circulation 2002; 106: 2296-8.

33. Versaci F, Gaspardone A, Tomai F, Ribichini F, Russo P, Proietti I,
Ghini AS, Ferrero V, Chiariello L, Gioffre PA, Romeo F, Crea F; Immunosuppressive Therapy for the Prevention of Restenosis after Coronary Artery Stent Implantation Study. Immunosuppressive Therapy for the Prevention of Restenosis after Coronary Artery Stent Implantation (IMPRESS Study). J Am Coll Cardiol 2002; 40: 1935-42.

34. Lincoff AM, Topol EJ, Ellis SG. Local drug delivery for the prevention of restenosis. Fact, fancy, and future. Circulation 1994; 90: 207084.

35. Wohrle J, Al-Khayer E, Grotzinger U, Schindler C, Kochs M, Hombach V, Hoher M. Comparison of the heparin coated vs the uncoated Jostent--no influence on restenosis or clinical outcome. Eur Heart J 2001; 22: 1808-16.

36. Lemos PA, Serruys PW, Sousa JE. Drug-eluting stents: cost versus clinical benefit. Circulation 2003; 107: 3003-7.

37. O’Neill WW, Leon MB. Drug-eluting stents: costs versus clinical benefit. Circulation 2003; 107: 3008-11.

38. Kereiakes DJ. Hippocrates revisited: the evidence for drug-eluting stents. Circulation 2003; 107: 3012-4.

39. Hong YJ, Jeong MH, Kim W, Lim SY, Lee SH, Hong SN, Kim JH, Ahn YK, Cho JG, Park JC, Cho DL, Kim H, Kang JC. Effect of abciximab-coated stent on in-stent intimal hyperplasia in human coronary arteries. Am J Cardiol 2004; 94: 1050-4.

40. Kim W, Jeong MH, Kim KH, Sohn IS, Hong YJ, Park HW, Kim JH, Ahn YK, Cho JG, Park JC, Cho DL, Kang JC. The clinical results of a platelet glycoprotein IIb/IIIa receptor blocker (abciximab: ReoPro)-coated stent in acute myocardial infarction. J Am Coll Cardiol 2006; 47: 933-8.

41. Fuster V, Badimon L, Badimon JJ, Chesebro JH. The pathogenesis of coronary artery disease and the acute coronary syndromes (1). N Engl J Med 1992; 326: 242-50.

42. Willerson JT, Golino P, Eidt J, Campbell WB, Buja LM. Specific platelet mediators and unstable coronary artery lesions. Experimental evidence and potential clinical implications. Circulation 1989; 80: 198-205. 